\title{
Hatékonyságnövelés szub- és szuperkritikus oldószerekkel
}

\author{
SZÉKELY Edit ${ }^{\mathrm{a}^{*}}$ \\ aBudapesti Müszaki és Gazdaságtudományi Egyetem, Kémiai és Környezeti Folyamatmérnöki Tanszék, \\ Müegyetem rkp. 3., 1111 Budapest, Magyarország
}

\section{Bevezetés}

A kritikus ponthoz közel az anyagok különleges tulajdonságokkal rendelkeznek, amely felhasználható arra, hogy eddig nem létező termékeket alkossunk meg, vagy hatékonyabban végezhessünk el egy elválasztási vagy szintetikus feladatot, esetleg csökkentsük a szerves oldószer felhasználást. ${ }^{1}$ A kritikus pont (nyomás és/vagy hőmérséklet) alatt szubkritikus, míg felett szuperkritikus állapotról beszélünk. Alkalmazás szempontjából a szubkritikus folyadékok és a szuperkritikus fluidumok a jelentősek, mert ezek viszonylag nagy sürüsége számottevő oldóképességgel jár együtt, a hagyományos folyadékokhoz viszonyítva viszkozitásuk viszonylag alacsony és a diffúzió gyors. Mindezek előnyösek az anyagátbocsátási folyamatok esetében.

Oldószerként a víz, az etanol és a szén-dioxid iparágtól függetlenül korlátozás nélkül alkalmazható. A szén-dioxid azonban az első kettővel szemben csak atmoszférikusnál nagyobb nyomáson képes jelentős mennyiségű anyagot oldani, oldószerként jellemzően szuperkritikus állapotban használják. Ökölszabályként elfogadható, hogy ekkor is apoláris, mérsékelt molekulatömegü komponensek oldódnak jól szén-dioxidban ${ }^{2}$, bár vannak kivételek, mint pl. a fluorozott ${ }^{3}$ polimerek. Az etanolt elterjedten használják adalékoldószerként a szén-dioxid polaritásának növelésére, extrakciós technikáknál max. $15 \%$-ban. ${ }^{4}$ Szuperkritikus fluidum kromatográfia mozgófázisaként rendszeresen valójában szubkritikus elegyet használnak, a szén-dioxid módosítójaként nem csak az etanol, hanem szinte bármilyen jellemző kromatográfiás oldószer alkalmazott. A szub- és szuperkritikus víz alkalmazásai az utóbbi évtizedben egyre intenzívebben kutatott területekké váltak, a részleges és teljes oxidációtól ${ }^{5}$ a biomassza cseppfolyósításon vagy elgázosításon ${ }^{6}$, az extrakción ${ }^{7}$ keresztül a nanoméretü fémoxidok $^{8}$ folyamatos elöállításáig számos területen bizonyult hatékonynak. Egyéb szub- és szuperkritikus oldószereket alkalmaznak az olajiparban ${ }^{9}$ (C3-C5 frakciók) vagy a polimeriparban ${ }^{10-11}$ (monomerek és elegyeik) egy-egy célfeladat megoldására, de ezek nem tekinthetőek általánosan elterjedtnek.

A Budapesti Müszaki és Gazdaságtudományi Egyetem (BME) Vegyipari Müveletek majd Kémiai és Környezeti Folyamatmérnöki Tanszékén 1986 óta a szuperkritikus fluidumokhoz kapcsolódóan folyamatosan aktív kutató-fejlesztő munka zajlik, amit több mint negyed évszázadon keresztül Simándi Béla professzor neve fémjelzett. Tanítványaiként törekszünk arra, hogy új lehetőségeken és új megoldások alkalmazásával mutassuk be a szuperkritikus oldószerek sokoldalúságát, valamint az új megoldásokon felül az ok-okozati összefüggéseket is felderítsük.

A nyomás alatti rendszerek alkalmazása akkor lehet gazdaságos és célszerü, ha egyértelmü, jól meghatározható előnye van az atmoszférikus alternatívával szemben, amennyiben ilyen létezik. Ez az előnye, a teljesség igénye nélkül, lehet jelentősen megnövekedett reakciósebesség, kiemelkedő szelektivitás, új és más módon nem előállítható termék pl. kompozit vagy kontrollált szemcseméret eloszlás, illetve kisebb környezetterhelés vagy energiaigény. Jelen cikk célja, hogy bemutassa a BME Nagynyomású oldószerek kutatócsoportban az elmúlt öt évben vizsgált legfontosabb területeket, egy-egy érdekesebb példával illusztrálva, és ezzel felkeltse az olvasó érdeklődését a szubés szuperkritikus oldószerek alkalmazásában rejlő lehetőségek és tudományos kihívások iránt.

2. Oldhatóság, sürüség, olvadáspont csökkenés és viszkozitás mérése nyomás alatt és az eredmények matematikai leírása

Bármely fejlesztés, kutatás megkezdésének, a kísérletek megtervezésének alapvető kérdése az, hogy ismertek-e a vizsgált rendszer fizikai-kémiai jellemzői. Ismert-e egy adott komponens vagy elegy oldhatósága a nyomás és hőmérséklet valamint elegyoldószer esetén a segédoldószer mennyiségének függvényében? Mivel az irodalomban ezek az adatok gyakran nem lelhetőek fel, eddig a szuperkritikus szén-dioxidban és segédoldószerekkel való elegyeiben való oldhatóság, az oldatsürüség, és -viszkozitás mérésére valamint az esetleges olvadáspont csökkenés megfigyelésére dolgozunk ki mérési technikákat.

\subsection{Oldhatóság}

Az oldhatóságot statikus illetve dinamikus módszerrel is meg lehet mérni. Dinamikus módszer esetén a szilárd anyagot egy oszlopba töltjük bele, majd ezen az ágyon keresztül állandó nyomáson és hőmérsékleten, kis térfogatárammal áramoltatjuk át a szuperkritikus szén-dioxidot. Az oldószer tömegárama nyomás alatt mérhető, a kioldott anyagmennyiséget nyomáscsökkentés és csapdázás után határozzuk meg. A gyakorlatban elsősorban gyengén oldódó vegyületek oldhatóságnak meghatározására alkalmas. Statikus módszer esetén a mérést egy változtatható térfogatú nagynyomású látóüveges cellában végezzük. A 
térfogat változtatásával egy adott koncentrációjú oldat opálosodási és kitisztulási nyomása határozható meg állandó hőmérsékleten. Szintén a statikus módszer egy válfaja, amikor egymással egyensúlyban levő folyadék és fluid fázist hozunk létre a változtatható térfogatú berendezésben, majd mindkét fázisból állandó nyomáson és hőmérsékleten mintát veszünk, amelyek koncentrációját független analitikai módszerrel meghatározzuk. Az 1. ábrán példaként egy prótikus ionos folyadék a di-2-etilhexil-ammónium2-etilhexanoát oldhatósága ${ }^{12}$ látható szén-dioxidban. A felület fölött homogén fluid fázis, a felület alatti körülmények esetében két egyensúlyi fázis alakul ki. Az ábrán látható kis móltört értékek átszámolva azt jelentik, hogy a vegyületnek megfelelő nyomás és hőmérséklet mellett (pl. $22 \mathrm{MPa} 55^{\circ} \mathrm{C}$ ) 10 tömeg\% feletti oldhatósága van. Az eredmény azért meglepő, mert az ionos folyadékokat a szakirodalom szén-dioxidban oldhatatlannak tekinti.

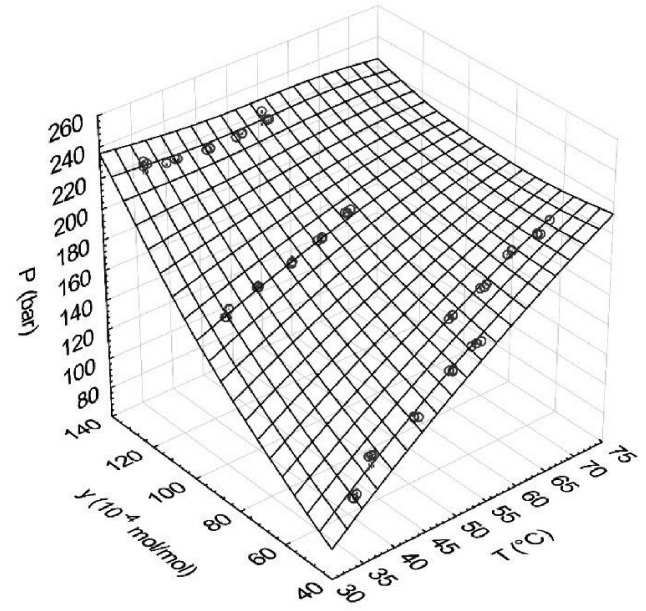

1. ábra. Szén-dioxid - di-2-etilhexil-ammónium-2-etilhexanoát elegy opálosodási nyomása az ionos folyadék móltört és a hőmérséklet függvényében.

\subsection{Sürüség és viszkozitás}

Az elegyek viszkozitásának és sürüségének az ismerete $a z$ elméletin felül gyakorlati szempontból is fontos, hiszen az alapvető müvelettani számításokhoz, egy technológia szimulációjához ezek az adatok szükségesek. A szakirodalomban még a sürüség esetén is többnyire a tiszta oldószer sűrüségével becslik az elegy összetétel-, nyomásés hőmérsékletfüggő sűrüségét, de a szuperkritikus elegyek, oldatok viszkozitásáról elvétve található csak információ. Kialakítottunk ezért a változtatható térfogatú látóüveges cellához csatlakoztatható nagynyomású esőtestes viszkozimétert. A 2. ábrán a relatív sürüség, ami az oldat mért sürüségének és az azonos nyomáson és hőmérsékleten mért tiszta szén-dioxid sürüségnek a hányadosa, látható a szén-dioxid móltört és a nyomás függvényében szén-dioxid - diaceton-alkohol elegy ${ }^{13}$ esetében. A diagramon érdemes megfigyelni, hogy a szén-dioxid kritikus nyomásához (7,36 MPa) közel már kis mennyiségü oldott anyagnak is jelentős hatása lehet a sürüségre, valamint az oldott anyag-tartalom növekedésével, azaz a szén-dioxid móltört csökkenésével az eltérés jelentőssé válik, az oldat sürüség többszöröse is lehet a tiszta szén-dioxid sürüségének.

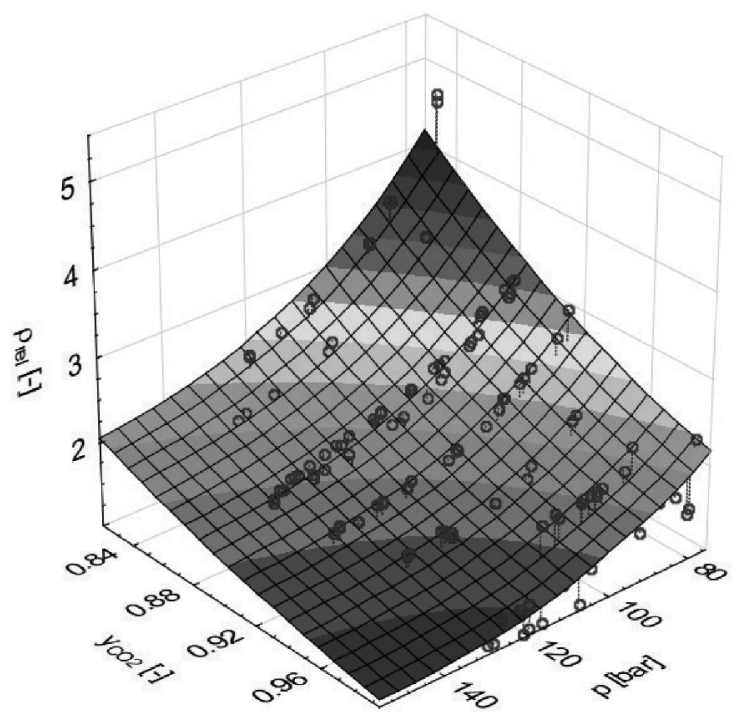

2. ábra. Diaceton-alkohol - szén-dioxid elegy relatív sürüsége a szén-dioxid móltört és a nyomás függvényében (változó hőmérséklet mellett)

Az oldatsürüség mérése lehetőséget teremt arra, hogy az elegyedési moltérfogatot számítani lehessen. Így a sürüségméréstől független oldhatósági adatok alapján állapotegyenletek (pl. Peng-Robinson) kölcsönhatási paramétereinek illesztése után a számított és a mért sürüségértékek összehasonlítása ellenőrzésre ad lehetőséget. Az oldhatóság matematikai leírása, a szükséges pontossággal, akár empirikus egyenletekkel, de még inkább állapotegyenletekkel lehetőséget teremt arra, hogy professzionális folyamatszimulátorban pl. egy szuperkritikus fluidum extrakció leírható legyen.

\subsection{Olvadáspont-csökkenés}

Bizonyos anyagok, elsősorban polimerek és ionos folyadékok olvadáspontja jelentősen lecsökkenhet szén-dioxid nyomás hatására, aminek oka a szén-dioxid nagymértékü beoldódása a szilárd fázisba. $\mathrm{Az}$ olvadáspont-csökkenés valamint a beoldódó szén-dioxid hatására bekövetkező viszkozitás csökkenés többek között az oka, hogy az ionos folyadékok és a szuperkritikus szén-dioxid rendszert sokféle feladatra alkalmasnak vélik. $\mathrm{Az}$ olvadáspont-csökkenés jelensége előnyös a mikronizálásra és kompozitok előállítására alkalmas PGSS ${ }^{14}$ (particles from gas saturated solutions) eljárás során is.

\section{Reakciók és elválasztómúveletek szén-dioxidban illetve vízben}

\subsection{Reakciók}

A szuperkritikus szén-dioxid alkalmazásának legfontosabb elönye az alacsony hömérséklet (min. $31^{\circ} \mathrm{C}$ ) és mérsékelt nyomás (min. 7,4 $\mathrm{MPa}$ ), ami kíméletes reakciókörülményeket tesz lehetővé. Emellett a szén-dioxid ilyen körülmények között inertnek tekinthető. Ezzel szemben a szub- és szuperkritikus víz $\left(\mathrm{T}_{\text {krit }} 374{ }^{\circ} \mathrm{C}\right.$, $\mathrm{P}_{\text {krit }} 22 \mathrm{MPa}$ ) reakcióképes közeg. Az alábbiakban ezzel a két oldószerrel segédoldószerek alkalmazása nélkül elért legújabb eredményeinkből mutatok be néhányat. 


\subsubsection{In situ diasztereomer sóképzés szuperkritikus szén-dioxidban}

A Simándi és Fogassy professzorok és munkatársaik által kidolgozott szuperkritikus extrakción alapuló rezolválási eljárás ${ }^{15}$ alapvető feltételezése az volt, hogy a szuperkritikus extrakció szerepe az oldhatatlan diasztereomer só és az elreagálatlan, szén-dioxidban oldható enantiomerkeverék elválasztása. A másfél évtizedes szisztematikus kutatás azonban rávilágított, hogy az elválasztó lépés nyomása és hőmérséklete jelentősen befolyásolhatja a rezolválás eredményességét. ${ }^{16} \mathrm{~A}$ tapasztalatok áttekintése után arra következtettünk, hogy a reakciók egyensúlyi állapota eltérő, mint a vákuumbepárlással elállított rendszer összetétele. Más szóval a diasztereomer sóképzési reakció lejátszódhat szuperkritikus szén-dioxid oldószerben is. A különböző rendszereken ${ }^{17-20}$ végzett részletes vizsgálatokból arra következtetésre jutottunk, hogy ha az egyik reagens jól oldódik szén-dioxidban ( $>1$ tömeg\%) a másik akárcsak kismértékben, de kimutathatóan oldódik $(>0,05$ tömeg\%) akkor a diasztereomer sóképzési reakció lejátszódik, bár ettől még nem szükségszerüen enantioszelektív. Amennyiben az egyik reagens oldhatatlanak tekinthetö, akkor a reakció megvalósítható időtartományon belül $(<1$ hét) nem játszódik le jó konverzióval. Ha mindkét komponens jól oldódik, a reakció rövid idő alatt $(<1$ óra) teljes konverziót is elérhet, egyéb esetben több napot vagy hetet is igénybe vehet.

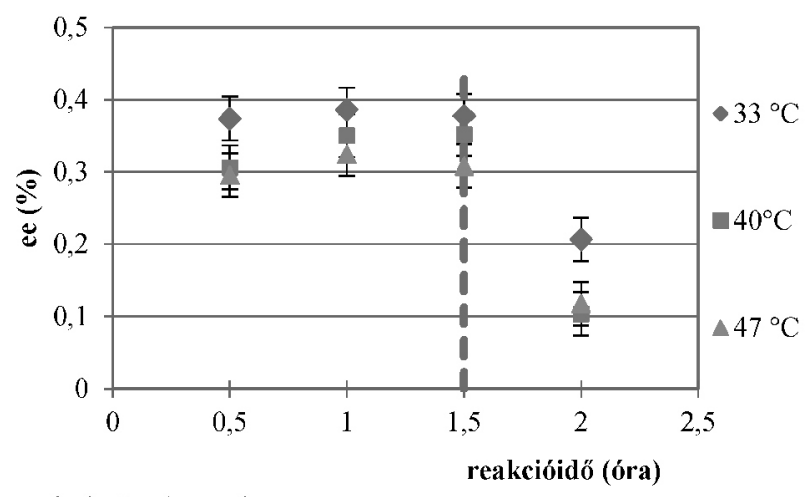

3. ábra. A fluid fázis enantiomer tisztasága cisz-krizantémsav (S)-2benzilamino-1-butanollal szén-dioxidban végzett in situ rezolválásakor 12,5 MPa nyomáson. Kék függőleges vonal az extrakciós mosás kezdetét jelzi.

$\mathrm{Az}$ in situ kristályosításon alapuló rezolválás hatékonyságához azonban nem csak a reakció lejátszódása szükséges, hanem az is, hogy az ezt követő extrakciós lépés során a diasztereomer kellőképpen stabil legyen. A 3. ábra a cisz-krizantémsav szén-dioxid oldószerben végzett rezolválása esetén mutatja a fluid fázisban mérhető enantiomer tisztaságot az idő függvényében a reakció alatt, illetve a mosási szakasz után. ${ }^{20}$ Mind a racém vegyület, mind a rezolválószer megfelelően oldódik a szén-dioxid fázisban, ezért már az első mintavételezés jó enantiomer tisztaságot mutat a fluid fázisban, amiből következik, hogy enantioszelektív diasztereomer sókiválás történt. A hőmérséklet emelése a diasztereomer só disszociációját elősegíti, így alacsonyabb fluidfázisbeli enantiomer tisztaságot eredményez. Látható, hogy a mosás során a diasztereomer só disszociál, ezzel a rezolválás hatékonysága leromlik.

A nyomás növelésével párhuzamosan a fluid fázis sürüsége és így oldóképessége nő, ami a cisz-krizantémsav rezolválása esetén nem kedvező.

Ezzel szemben például az ibuprofen $-R$-feniletán-1-amin in situ sóképzése ${ }^{17} 20 \mathrm{MPa}$ nyomáson $40-50{ }^{\circ} \mathrm{C}$ hőmérsékleten 70-80\%-os enantiomer tisztaság mellett kiváló rezolválást tesz lehetővé, míg $10 \mathrm{MPa}$ nomáson csak 30\% enantiomer tisztaság érhető el. A nyomás emelése a reakciósebességet és az egyensúlyi enantiomer tisztaságot egyaránt növeli.

\subsubsection{Enzimkatalizált kinetikus rezolválás szuper- kritikus szén-dioxidban}

Bizonyos enzimek és enzimkészítmények, elsősorban a lipázok, megörzik aktivitásukat szuperkritikus szén-dioxid oldószerben is. Még a lipázok is érzékenyek azonban a nem optimális víztartalomra, vagy a nyomás hirtelen változására. Éppen ezért az enzimkatalizált reakciót akkor érdemes szuperkritikus szén-dioxidban végezni, ha:

- Lényegesen nagyobb reakciósebesség érhető el,

- kiemelkedő szelektivitás,

- vagy a reakció és a termék-szubsztrát elválasztás összekapcsolása lehetséges és hatékony.

Az elmúlt időszakban elsősorban a harmadik területtel, a reakció és a nyomáscsökkentésen alapuló enzim visszamaradó szubsztrát - $\quad$ termékelválasztással foglalkoztunk. Minden mintapélda esetén rendkívül szelektív és gyors volt az enzimkatalízis, a kihívást az elválasztási lépés reakcióhoz való kapcsolása jelentette. Abban az esetben például, ha egy szén-dioxidban oldható szubsztrátból oldhatatlan termék keletkezik (pl. aminosav), akkor a reakció után a visszamaradó szubsztrát szén-dioxidos extrakcióval elválasztható, majd az enzimkészítmény felületéről az aminosav vizes mosással eltávolítható. ${ }^{21}$ Észterezési reakciók esetén az észterező ágens szénlánchosszának optimális megválasztásával nem csak a reakció szelektivitása és sebessége maximalizálható, hanem a termék és a szubsztrát oldhatóság különbsége is megnövelhető és így az elválasztás frakcionált nyomáscsökkentéssel lehetővé válik. ${ }^{22}$

\subsubsection{Részleges oxidáció szuperkritikus vízben}

A szuperkritikus vizes oxidációt (SCWO) rendszeresen alkalmazzák nehezen vagy csak kockázatosan kezelhető ipari szennyvizek kezelésére, mert rövid átlagos tartózkodási idő mellett (másodperc - perc nagyságrend) teljes bomlás érhető el. A rövid szükséges átlagos tartózkodási idő oka az anyagátbocsátási ellenállás hiánya, hiszen a szuperkritikus víz és az oxigén (levegő) egymással korlátlanul elegyednek. Hátrány jelent a nagyfokú korróziós kockázat valamint a nagy nyomás. A SCWO az átlagos tartózkodási idő vagy az oxigén mennyiségének szabályozásával részlegesen is végrehajtható, amit szintetikus vagy regenerálási célra fel lehet esetleg használni. ${ }^{23}$ Saját munkánkban összeállítottunk 
egy folyamatos részleges szuperkritikus vizes oxidációs berendezést, amelyen elért eredményeket egy tesztrendszeren, a toluol benzoesavvá történő részleges oxidációjának mintapéldáján mutatom be az 4. ábrán.

A 4. ábra a konverzió és a termelés a 4,7 másodperces átlagos tartózkodási idő mellett (kb. 48\% konverzió, 20\% termelés,) azonos napon mért mérések eredményétől való eltérését mutatja be. Látható, hogy a növekvő átlagos tartózkodási idő a konverzió növekedését, de a termelés csökkenését eredményezi, azaz a benzoesav is továbboxidálódik a reakciókörülmények között. Mivel a SCWO rendkívül gyors reakció, a részleges oxidációhoz nagyon precízen, tizedmásodperces nagyságrendben kell szabályozni az átlagos tartózkodási időt. Ugyanez lehet a módszer előnye is, hiszen nagy termékmennyiség előállításához is kis reaktortérfogatok szükségesek.

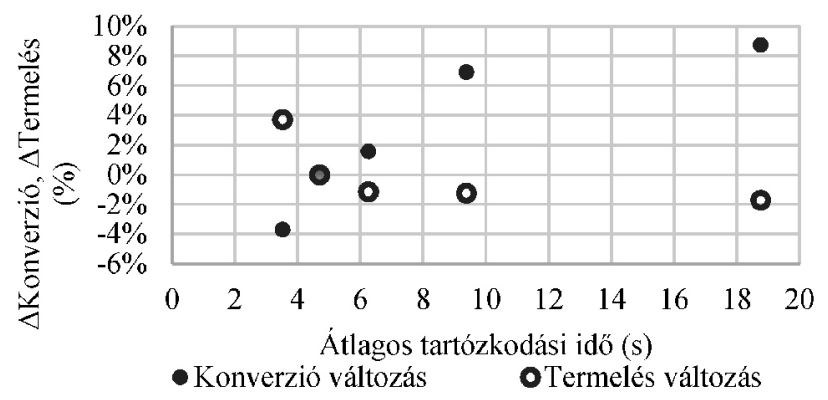

4. ábra. Az átlagos tartózkodási idő hatása részleges szuperkritikus vizes oxidáció esetén (körülmények: $400{ }^{\circ} \mathrm{C}, 30 \mathrm{MPa}, 1,5$-szeres oxidálószer felesleg) ${ }^{24}$

\subsubsection{Biomassza bontás szubkritikus vízben}

A 3.1.3. alpontban röviden bemutatott részleges szuperkritikus vizes oxidációval megegyező körülmények között, de oxigén kizárása mellett végezhető biomassza elgázosítás metán vagy hidrogén termelési céllal, illetve ennél kisebb nyomáson $(<20 \mathrm{MPa})$ és alacsonyabb hőmérsékleten (200-350 ${ }^{\circ} \mathrm{C}$ ) a biomassza vagy egyéb hulladékok elfolyósítása lehetséges. ${ }^{25}$ Saját eredményeink szerint 20-40 perc reakcióidő mellett mezőgazdasági hulladékból akár 40-50 tömeg\% bio-olaj is előállítható.

\subsection{Egyéb diffúziókontrollált folyamatok}

A szub- és szuperkritikus fluidumok egyik legfontosabb elönye, hogy a diffúzió ezekben az oldószerekben nagyságrendekkel gyorsabb, mint folyadékokban. Az alábbiakban néhány speciális alkalmazást mutatok be, amely ezt a tulajdonságot használja fel.

\subsubsection{Aerogélek}

Az aerogélek, akár szilika akár szén aerogélekre gondolunk, előállításának fontos lépése a polikondenzáció vizes közegben, majd az azt követő oldószercsere után a pórusokat kitöltő vizes oldószer lecserélése levegőre úgy, hogy a folyamat közben sosem keletkezik fázishatárfelület a pórusok belsejében. A tématerület László Krisztina professzor (BME) aerogél kutatásaihoz kapcsolódik. A megfelelő gélszerkezet előállításának kritikus lépése a szárítás, ahol a nagynyomású szén-dioxidos extrakció szükséges. Alapvetően három eljárás létezik:

1. Magát a pórusokat kitöltő oldószert hevíteni nyomás alatt a kritikus pontja fölé, majd ezt kicserélni nyomás alatt levegőre, ezután csökkenteni a nyomást. Ez a módszer a jellemző oldószerek (víz, etanol, metanol, aceton) magas kritikus hőmérséklete miatt általában nem célszerü.

2. A pórusokban levő a vizet teljesen lecserélni szerves oldószerre, majd a szerves oldószert nyomás alatt folyadék halmazállapotú szén-dioxidra. Amikor már szinte csak folyadék szén-dioxid tölti ki a pórusokat, akkor felmelegíteni (nyomás alatt) a szén-dioxid kritikus pontja fölé a rendszert, majd ezen a hömérsékleten lecsökkenteni a nyomást.

3. A szén-dioxid kritikus pontjánál magasabb hőmérsékleten szuperkritikus szén-dioxidos extrakcióval elvégezni az oldószercserét, majd állandó hőmérsékleten a nyomáscsökkentést.

Azt tapasztaltuk, hogy a 3. módszer teszi lehetővé a gélek leggyorsabb szárítását, a legkisebb zsugorodás mellett, aminek az oka az, hogy a szerves oldószer szén-dioxidra való kicserélődése gyorsabban játszódik le a gyorsabb diffúzió miatt, mint a 2 . esetben. ${ }^{26}$

\subsubsection{Szén nanocsövek}

A szén nanocsövekbe a kis méretü apoláris üregük miatt nehéz molekulákat belejuttatni. Mivel ez a tér eredendően nem keverhető, a diffúzió lesz a meghatározó a folyamatban. Kamarás Katalin professzor (MTA Wigner FK SZFI) kutatócsoportjával együttmüködésben alkalmas módszert dolgoztunk ki arra, hogy különböző anyagokat (pl. fullerén ${ }^{27}$, koronén ${ }^{28}$, lumineszcens komplex $^{29}$ ) a szuperkritikus szén-dioxid diffúziós folyamatokat elősegítő tulajdonságát kihasználva a nanocsövek belsejébe rövid idő alatt bejuttassunk. A módszer érdekessége, hogy ezen anyagok egyike sem oldódik kimutatható mértékben szuperkritikus szén-dioxidban.

\subsubsection{Impregnálás}

A nanocsöveknél és az aerogéleknél elért sikerek, valamint az irodalomban megtalálható aerogélek, textilek, faanyagok polimerek sikeres impregnálási alkalmazásai arra sarkalltak, hogy polimerek alacsony hőmérsékletü festésénél ${ }^{30}$ is vizsgáljuk meg a szén-dioxid alkalmazhatóságát. A polimeriparban a szuperkritikus szén-dioxidot a polimerizációs reakció oldószereként, lágyítószerként, habosításra használják. ${ }^{11}$

Az 5. ábrán szén-dioxidban ditizonnal színezett polikarbonát gyöngyök láthatóak. Látható, hogy az impregnálás időigényes folyamat. A színintenzitás nő a növekvő idővel. Ahogy az 5. ábrán is látható, kis mennyiségű segédoldószer alkalmazása is jelentősen befolyásolhatja egy adott folyamat végeredményét, többnyire az oldhatóságot módosító hatásán keresztül. A festék oldhatóságának növelésével (nyomás növelés, segédoldószer alkalmazása a színezés gyorsul, de hosszabb érintkezési időnél a polimerhez való affinitás a meghatározó. 

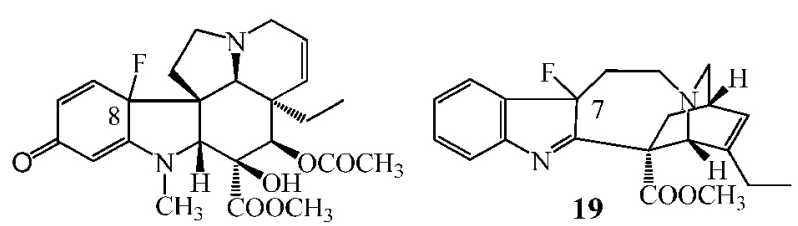

18

5. ábra. Ditizonnal színezett polikarbonát gyöngyök ${ }^{31}$

\section{Elegyoldószerek alkalmazása}

\subsection{Növényi hatóanyagok kinyerése segédoldószerrel}

Világszinten ma már sok száz üzemi méretű extrakciós berendezés üzemel. Bizonyos esetekben azonban, mint pl. ha a célunk alkaloidok kinyerése, a szén-dioxid oldóképessége nem elegendően nagy, legalábbis a szokásos $50 \mathrm{MPa}$ alatti nyomástartományban. Az oldhatóság és az extrakciós sebesség növelésére a segédoldószerek alkalmazása kínál megoldást. Segédoldószerként vizet, etanolt használnak leggyakrabban, mi is ezeket használjuk. Az utóbbi években az érdeklődésünk középpontjába atmoszférikus és nagynyomású kivonási módszerek kombinációja került, aminek célja egy alapanyagból több különböző hatású kivonat elöállítása, ami hatékonyabb alapanyag felhasználást tesz lehetővé. ${ }^{32,33}$ A módszer kivonatok frakcionálására is alkalmas. Mintapéldaként a macskakaromra kidolgozott két megoldás sematikus vázlata látható a 6 . ábrán. A növény alkaloidjainak immunerősítő és antivirális hatást tulajdonítanak. A csersavban dús frakció elegendően nagy koncentrációjú, hogy alkalmas természetes börcserzőszernek. ${ }^{34}$

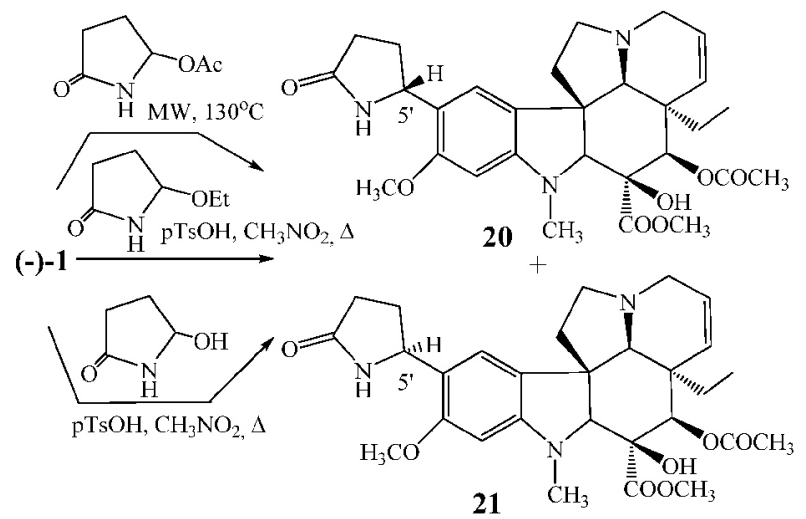

6. ábra. Macskakarom kéreg frakcionálása szuperkritikus (SFE) segédoldószeres és atmoszférikus extrakciós technikák kombinálásával.

\subsection{Antiszolvens frakcionálás}

$\mathrm{Az}$ antiszolvens eljárások elve éppen ellentétes a segédoldószer alkalmazásával. Itt a szerves oldószer jó oldószere a komponenseknek, amelyeket a szén-dioxid, mint anitszolvens hozzáadásával csapunk ki. A technikát finom porok elöállítására, mikronizálásra használják. Antiszolvens frakcionálásról akkor beszélünk, amikor a kicsapás mellett bizonyos komponensek oldatban maradnak és a kicsapást követő extrakciós lépés során eltávolítjuk az értékesebb komponensek mellől, így egy lépésben jelentős mértékben tisztul is a termék.

\subsubsection{Kivonatok finomítása}

Természetes kivonatok, növényi extraktumok rendkívül sok komponensből állnak. Ezek jellemzően lekvár vagy zselé állagú, nehezen kezelhető, többnyire sötét színü ún. szárazextraktok, amelyeket felhasználás előtt a legtöbb esetben további feldolgozási, tisztítási lépéseknek kell alávetni.

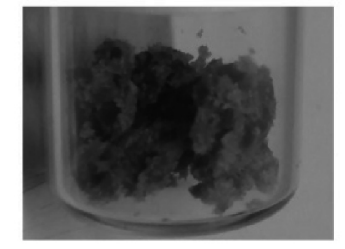

Kevertetéses metanolos szárazextrakt, 16 tömeg\% allantoin

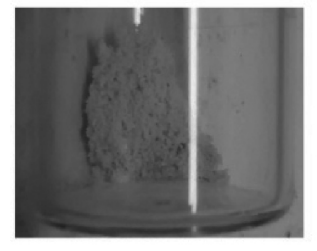

Antiszolvens $\left(13 \mathrm{MPa}, 40^{\circ} \mathrm{C}\right)$ 24 tömeg\% allantoin
7. ábra. Fekete nadálytő kivonat antiszolvens frakcionálása ${ }^{35}$

A feladat megoldására bizonyos esetekben, elsősorban poláris oldószerekkel magasabb hőmérsékleten (célszerüen rövid kontaktidő mellett) elöállított oldatok esetében, az oldószer bepárlása utáni további hagyományos finomítási lépések helyett az azonnali szén-dioxidos antiszolvent frakcionálás alkalmas lehet. A 7. ábrán fekete nadálytő antiszolvens frakcionálásnak eredményei láthatóak. A cél porszerü, homogén jól adagolható és kezelhető kivonat előállítása, nagy allantointartalommal.

\subsubsection{Rezolválás}

$\mathrm{Az}$ antiszolvens frakcionálás alkalmas diasztereomer sóképzésen alapuló rezolválásra is. Más jellegű vegyületeknél alkalmas azonban, mint a csak szén-dioxidot alkalmazó eljárások. Míg a csak szén-dioxidos módszerek csak apoláris racém vegyületek esetén alkalmasak, és primer aminok esetén az alkalmazásuk nem célszerü, az antiszolvens eljárásnak nincsenek ilyen korlátjai. Azonban az antiszolvens módszerhez a diasztereomer sónak sokkal stabilabbank kell lennie, eddig még diasztereomer komplexek esetén nem sikerült alkalmaznunk. A módszer széles mólaránytartományban használható, és a nyomás, hőmérséklet és szerves oldószer / szén-dioxid arány is befolyásolja a rezolválhatóságot a legtöbb esetben. Cisz-permetrinsav (R)-feniletán-1-aminnal ${ }^{36}$ való antiszolvens rezolválása esetén (8. ábra) $40^{\circ} \mathrm{C}$ hömérsékleten kiemelkedő enantiomer tisztaságot (ee) értünk el 13-17 MPa között. $17 \mathrm{MPa}$ felett gyakorlatilag nem képződött szilárd fázis így enantiomer megkülönböztetés sem lehetett, míg $13 \mathrm{MPa}$ alatt racém diasztereomer só vált ki nagy mennyiségben, eltérő kristályszerkezetben, mint a középső nyomástartományban.

A módszer alkalmazható enantiomerkeverékek továbbtisztítására is, akár a diasztereomer sók 
átkristályosításával, akár szén-dioxidban gyengén oldódó enantiomer keverékek esetén közvetlenül is. ${ }^{37}$

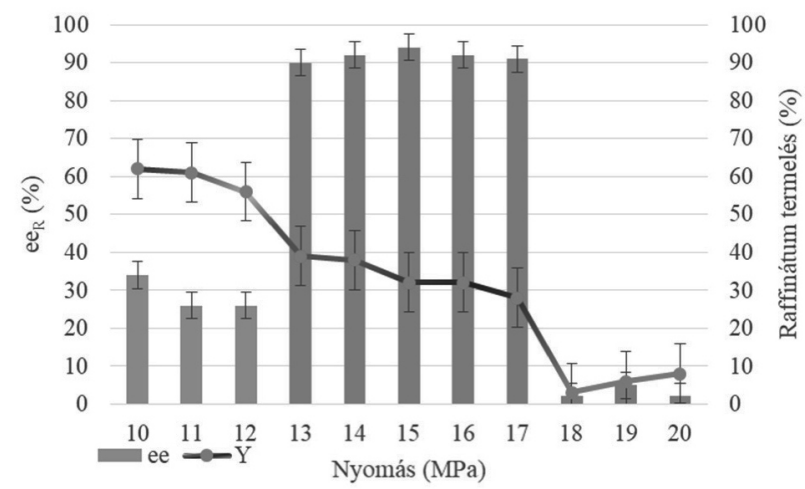

8. ábra. Cisz-permetrinsav (R)-feniletán-1-aminnal való antiszolvens rezolválása esetén a nyomás hatása az enantiomer tisztaságra és a termelésre.

Joggal vetődik fel azonban az a kérdés, hogy mi az előnye a nagynyomású antiszolvens frakcionálásnak vagy kristályosításnak az atmoszférikus átkristályosításhoz képest. Amellett, ami az általános tulajdonsága a szub- és szuperkritikus oldószereknek, azaz a nyomással, hőmérséklettel és összetétellel széles határok között változtatható oldóképesség és mint bemutattam a szelektivitás is, az antiszolvens eljárás esetén a kicsapás pillanatszerü.

\section{Hivatkozások}

1. Simándi, B.; Sawinsky, J. Olaj Szappan Kozmetika 1996, 45, 3-11.

2. Székely, E.; Mucsina, G.; Tokai, Zs.; Dudás, J.; Vágó, Á.; Kalocsai, P.; Törő, M.; Simándi, B. Szuperkritikus Oldószerek Müveleti és Analitikai Alkalmazása, Budapest, Magyarország, 2012.05.24. p. 18.

3. Wood, C. D.; Yarbrough, J. C.; Roberts, G.; DeSimone, J. M. In Supercritical carbon dioxide in polymer reaction engineering; Kemmere, M. F.; Meyer, T. (eds) Wiley-VCH Verlag GmbH., Weinheim 2005.

4. Bertucco, A.; Vetter, G. (eds.), High Pressure Process Technology: Fundamentals and Applications, Amsterdam: Elsevier, 2001.

5. Marrone, P. A. J. of Supercrit. Fluids 2013, 79, 283-288. https://doi.org/10.1016/j.supflu.2012.12.020

6. Pavlovič, I.; Knez, Ž.; Škerget, M. J. Agric. Food Chem. 2013, 61, 8003-8025. https://doi.org/10.1021/jf401008a

7. Gbashi, S.; Adebo, O. A.; Piater, L.; Madala, N. A.; Njobeh, P. B. Sep. Pur. Reviews 2017, 46, 21-34. https://doi.org/10.1080/15422119.2016.1170035

8. Gruar, R. I.; Tighe, C. J.; Southern, P.; Pankhurst, Q. A.; Darr, J. A. Ind. Eng. Chem. Res. 2015, 54, 7436-7451. https://doi.org/10.1021/acs.iecr.5b01817

9. Meyers R. A., Handbook of Petroleum Refining Processes, McGraw-Hill Education 2016.

10. Kemmere, M. F.; Meyer, T. (eds.), Supercritical carbon dioxide in polymer reaction engineering, Wiley- $\mathrm{VCH}$ Verlag GmbH., Weinheim 2005. https://doi.org/10.1002/3527606726

\section{5. Összefoglalás}

A szub- és szuperkritikus oldószerek közös előnyös tulajdonságai a nyomással, hőmérséklettel és segédoldószer alkalmazása esetén a segédoldószer mennyiségével széles tartományban szabályozottan változtatható sürüség, oldóképesség. A gyors diffúzió miatt az anyagátbocsátási folyamatok gyorsabbak, mint folyadékokban. A BME Kémiai és Környezeti Folyamatmérnöki Tanszékén a több, mint 30 éves múltra visszatekintő kutatócsoport elmúlt öt évének munkáiból mutat be mintapéldákat a közlemény a reakcióktól a rezolváláson, extrakción, impregnáláson át az antiszolvens frakcionálásig. A kutatások célja olyan környezetkímélö, hatékony módszerek és megoldások kifejlesztése az elméleti háttér megértéséhez szükséges alapmérési módszerek kidolgozásától a valós problémák megoldásáig, amely a nagynyomású oldószerek speciális előnyeit felhasználja.

\section{Köszönetnyilvánítás}

A megfogalmazott összegző, átfogó értékelések nem születhettek volna meg a kutatócsoport tagjainak áldozatos munkája nélkül. Külön köszönet illeti a hivatkozott saját közlemények összes társszerzőjét valamint a munkát támogató cégeket és szervezeteket (jelenleg OTKA K108979). Ezúton is szeretném kifejezni személyes hálámat és nagyrabecsülésemet Simándi Béla és Fogassy Elemér professzorok iránt, akik a szuperkritikus szén-dioxidban végzett rezolválás kutatásában világszinten elsők voltak.

11. Saldivar-Guerra, E.; Vivaldo-Lima, E. Handbook of Polymer Synthesis, Characterization, and Processing, John Wiley \& Sons, Hoboken, New Jersey, 2013. https://doi.org/10.1002/9781118480793

12. Péter-Szabó, B.; Kelemen, Zs.; Dudás, J.; Nyulászi, L.; Székely, E. Szuperkritikus oldószerek analitikai és műveleti alkalmazása konferencia. 2015.05.21 p. 37.

13. Lévai, Gy. Dipomamunka, BME, 2013

14. Weidner, E. J. of Supercritical Fluids 2009, 47, 556-565. https://doi.org/10.1016/j.supflu.2008.11.009

15. Fogassy, E.; Simándi, B.; Ács, M.; Szili, T.; Deák, A.; Kemény, S.; Sawinsky, J.; Manczinger, J.; Benkéné Lődy, I.; Varga, K.; Lantos, B. MSZ 212905, 1993.

16. Simándi, B. MTA doktori értekezés, Budapest, 2007.

17. Bánsághi, Gy.; Szekely, E.; Sevillano, D.M.; Juvancz, Z.; Simandi, B. J. of Supercritical Fluids 2012, 69, 113-116. https://doi.org/10.1016/j.supflu.2012.05.016

18. Lörincz, L.; Sohajda, T.; Székely, E. Műszaki Kémiai Napok 2017: Veszprém, Magyarország, 2017.04.25-2017.04.27.

19. Varga, D.; Bánsághi, Gy.; Martínez Pérez, J. A.; Miskolczi, S.; Hegedűs, L.; Simándi, B.; Székely, E. Chem. Eng. Technol. 2014, 37, 1885-1890. https://doi.org/10.1002/ceat.201300720

20. Varga, D. Diplomamunka, BME, 2013.

21. Utczás, M.; Székely, E.; Tasnádi, G.; Monek, É.; Vida, L.; Forró, E.; Fülöp, F.; Simándi, B. J. Supercritical Fluids 2011, 55, 1019-1022. https://doi.org/10.1016/j.supflu.2010.10.024

22. Varga, Zs.; Kmecz, I.; Székely, E. 16th European Meeting on Supercritical Fluids, Lisbon, Portugália, 2017.04.25-2017.04.27. p. 118. 
23. Garcia-Verdugo, E.; Fraga-Dubreuil, J.; Hamley, P. A.; Thomas, W. B.; Whiston, K.; Poliakoff M. Green Chem. 2005, 7, 294-300. https://doi.org/10.1039/b419098j

24. Tárkányi, M., Diplomamunka, BME, 2016.

25. Tekin, K.; Karagoz, S.; Bektao, S. Renewable and Sustainable Energy Reviews 2014, 40, 673-687. https://doi.org/10.1016/j.rser.2014.07.216

26. Czakkel, O.; Székely, E.; Koczka, B.; Geissler, E.; László, K. Microporous Mesoporous Mater. 2012, 148, 34-42. https://doi.org/10.1016/j.micromeso.2011.07.008

27. Botos. Á.; Khlobystov, A.N.; Botka, B.; Hackl, R.; Székely, E.; Simándi, B.; Kamarás, K. Phys Status Solidi B 2010, 247, 2743-2745. https://doi.org/10.1002/pssb.201000375

28. Botka, B.; Füstös, M.E.; Klupp, G.; Kocsis, D.; Székely, E.; Utczás, M.; Simándi, B.; Botos, Á.; Hackl, R.; Kamarás, K. Phys Status Solidi B. 2012, 249, 2432-2435.

https://doi.org/10.1002/pssb.201200349

29. Maggini, L.; Füstös, M-E.; Chamberlain, T.W.; Cebrián, C.; Natali, M.; Pietraszkiewicz, M.; Pietraszkiewicz, O.; Székely, E.; Kamarás, K.; De Cola, L.; Khlobystov, A.N.; Bonifazi, D. Nanoscale 2014, 6, 2887-2894.

https://doi.org/10.1039/c3nr05876j

\section{Increasing efficiency with sub- and supercritical solvents}

The subcritical and supercritical solvents, also called pressurized solvents, are known for their well controllable solvent properties by modifying pressure, temperature and in case of using a mixed solvent by composition as well. One of the major strength of these solvents compared to traditional liquids is the fast diffusion resulting in reduced mass transfer limitation. Our research group at the Department of Chemical and Environmental Process Engineering of Budapest University of Technology and Economics (BME) was established in 1986 and it is dedicated to demonstrate novel application possibilities of pressurized solvents. Our research aims to develop efficient, environmentally benign processes including development of experimental techniques to better understand fundamentals if needed and solving real problems of industry as well. This paper presents some interesting topics and results from our work in the last five years from chemical reactions through optical resolution, extraction, impregnation to antisolvent fractionation to engage the reader with the beauty of the pressurized solvent research field.

\section{Measurement and modelling of solubility, viscosity, density, melting point depression}

Before any experimental research could be planned, we need information on the phase equilibrium and on the properties of the phases involved. However, solubilities of even single compounds in pressurized fluids often cannot be found in the literature and that of mixtures is almost never described detailed enough. Thus we developed and validated own dynamic and static solubility measurement techniques for solutes of low and good solubilites as well. In Fig 1. the temperature and composition dependent cloud point pressures are plotted of a protic ionic liquid (IL). We observed upto 10 mass \% solubility of the IL in supercritical carbon dioxide, while ILs are in principle regarded as being non-soluble in carbon dioxide. Density and viscosity of a
30. Varga, D.; Alkin, S.; Gluschitz, P.; Péter-Szabó, B.; Székely, E.; Gamse, T. J. Supercritical Fluids 2016, 116, 111-116. https://doi.org/10.1016/j.supflu.2016.05.018

31. Kótai, A., Diplomamunka, BME, 2017.

32. Calvo, A.; Morante, J.; Plánder, Sz.; Székely, E. Acta Aliment. Hung. 2017, 46, 27-34.

https://doi.org/10.1556/066.2017.46.1.4

33. Calvo, A.; Dévényi, D.; Kószó, B.; Sanz, S.; Oelbermann, A. L.; Maier, M.; Keve, T.; Komka, K.; Gamse, T.; Weidner, E.; Székely, E. J. Supercritical Fluids 2017, 125, 50-55. https://doi.org/10.1016/j.supflu.2017.01.018

34. Maier, M.; Oelbermann, A. L.; Renner, M.; Weidner, E. Ind. Crops Prod. 2017, 99, 19-26. https://doi.org/10.1016/j.indcrop.2017.01.033

35. Czeczon, Zs., Szakdolgozat, BME, 2017.

36. Bánsághi, Gy.; Lőrincz, L.; Szilágyi, I.M.; Madarász, J.; Székely, E. Chem. Eng. Technol. 2014, 37, 1417-1421. https://doi.org/10.1002/ceat.201300718

37. Körösi, M.; Madarász, J.; Sohajda, T.; Székely, E.; 16th European Meeting on Supercritical Fluids Lisbon, Portugália, 2017.04.25-2017.04.27. p. 81.

pressurized solution are often estimated by the known pressure and temperature dependent density and viscosity of the solvent. By systematic measurement of the two properties of solutions, large deviations were found, and example is presented in Fig. 2 for diacetone alcohol $-\mathrm{CO}_{2}$ mixture. An interesting phenomenon is also the melting point depression in presence of carbon dioxide, which can be observed in a view cell.

\section{Applications}

Reactions, formulations, extractions were developed in pure pressurized (sub- or supercritical) water and carbon dioxide and in mixtures of carbon dioxide with organic solvents.

Enantioselective enzyme catalyzed kinetic resolutions ${ }^{21-22}$ and partial diastereomeric salt formation based optical resolutions ${ }^{17-20}$ are possible and in some cases are efficient in supercritical carbon dioxide. While enantioselectivities and reaction rate might be increased by working at the optimal operational parameters, the major advantage of allying supercritical fluids is the possibility of coupling the reaction with a selective separation as supercritical fluid extraction followed by sequential pressure drop based recovery of the solutes.

Sub- and supercritical water is a useful solvent for fast complete or selective degradation. Supercritical water oxidation is applied for solving difficult waste water purification problems, while partial supercritical water oxidation might lead the degradation intermediers within a seconds' scale average residence time. By excluding oxygen, under supercritical conditions the hydrothermal gasfication, while under subcritical conditions the hydrothermal liquefaction are promising techniques for biomass based biogas or bio-oil production. 
Diffusion controlled processes can be efficiently enhanced by using supercritical fluids. Enzymatic catalysis also sees its benefits, but various impregnations from polymers ${ }^{30-31}$ (Fig. 5.) to carbon nanotubes ${ }^{27-29}$, solvent exchange within porous structures as aerogels ${ }^{26}$ can also become possible if supercritical fluids, mainly carbon dioxide is used to accelerate diffusion within the solid phase.

A supercritical or subcritical fluid, being a non-polar solvent, is often not sufficient alone to obtain the desired separation. Cosolvents (alcohols, esthers, ketones, water etc.) applied as minor additives enhance the dissolving power of the solvent significantly. On the other hand this may lead in meantime to reduced selectivity.

From a single plant several different bioactive fractions ${ }^{32-33}$ might be obtained by fine-tuned extractions in series. For example from cat's claw bark a fraction rich in pentacyclic alcaloids supposed to have immune stimulant and antiviral effects and a fraction rich in tannin applicable in low environmental impact tanning of leather can be obtained by the combination of supercritical carbon dioxide extraction with ethanol cosolvent and hydroalcoholic extraction.

Antisolvent precipitation or fractionation also uses mixtures of an organic and a supercritical solvent, but the main aim is to instantaneously decrease the dissolving power of the organic solvent by adding the antisolvent. Carbon dioxide, either liquid of supercritical is a suitable antisolvent, because it is very well soluble in most of the organic solvents, and above a certain pressure it is typically already completely miscible.
Dry extracts obtained from plants, either obtained by conventional solvent extraction, pressurized liquid extraction or supercritical fluid extraction, are typically gelly, difficult to handle. Antisolvent fractionation of the extract with pressurized carbon dioxide as antisolvent may lead to selective precipitation of the required compounds in a powder form (Fig 7.)

Antisolvent fractionation can also be efficiently applied for selective precipitation of diastereomeric salts. It was found, that while typically the organic solvent to carbon dioxide ratio plays the major role regarding selectivity of the precipitation, in certain cases pressure influences so significantly the solubility and dissociation of the two different diastereomeric salts that it is possible the maximize the difference resulting in outstanding enantioselectivity. ${ }^{36}$ Furthermore, antisolvent fractionation is also a viable tool of enantiomeric enrichment either by recrystallization of diastereomeric salts, or by selective precipitation of enantiomeric mixture. ${ }^{37}$

While the purpose of this paper and of especially this English summary was to draw the attention of the reader of the various fields where sub and supercritical fluid might be the best choice, I would like to thank here also all coauthors of the common papers referred their enthusiastic work in this field, all our former and current sponsors from industry and public bodies for believing in this field, and the pioneers of diastereomeric salt based enantioseparation with supercritical extraction, Prof. Simándi and Prof. Fogassy, for being as great persons and researchers as they always have been. 